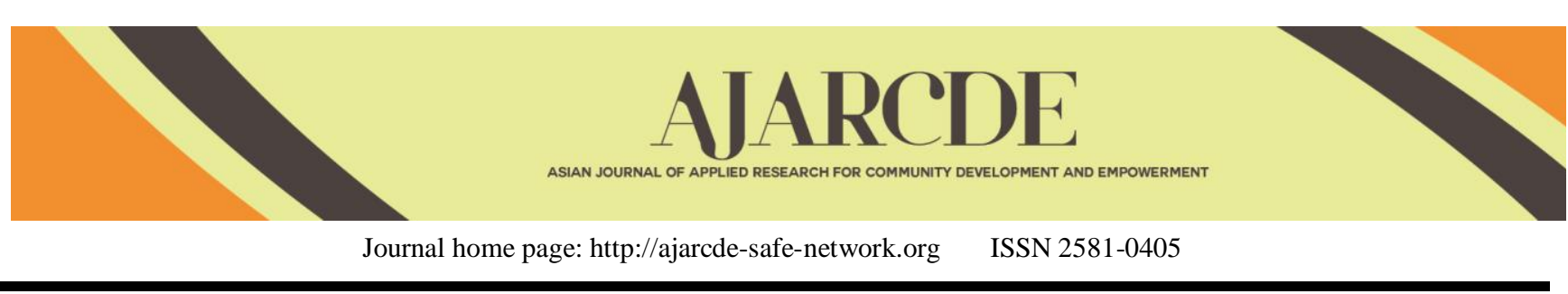

\title{
Mitigation and Adaptation Peatland through Sustainable Agricultural Approaches in Indonesia: a Review
}

\author{
Soni Sisbudi Harsono \\ Faculty of Agriculture Technology - University of Jember (UNEJ). Address: Jalan Kalimantan 57 JEMBER - Jawa Timur - Indonesia,
}

\section{ARTICLE INFO}

Article History:

Received: 25 January 2020

Final Revision: 28 February 2020

Accepted: 05 March 2020

Online Publication: 05 March 2020

\section{KEYWORDS}

peatland, mitigation, adapatation, suistanable agriculture, global warming

\section{CORRESPONDING AUTHOR}

*E-mail: s_harsono@yahoo.com

\section{A B S T R A C T}

Rapid and massive damage on peatland mainly due to conversion to a production system in the presence of perennial crops for the purpose of financially profitable agribusiness, such as oil palm plantations and other industries, can lead to increased greenhouse gases. Greenhouse gas emissions are influenced by biophysical processes are complex, such as peat decomposition and compaction, nutrient availability, soil water content, and soil water content. When land clearing increased significantly in the area of peatland is not followed by the application of sustainable agriculture, then, will peat land would become flammable and the greater the volume of $\mathrm{CO}_{2}$ gas that emits into the atmosphere that causes global warming and climate change. This paper reviews about the expansion of agriculture and plantations on peatland and action needs to be done by following sustainable agricultural systems. Noting the condition of peatland that have been severely damaged due to the expansion of oil palm plantations, the mitigation and adaptation in the land through sustainable agricultural system is highly recommended to reduce the more severe damage to the peatland areas and minimize the release of $\mathrm{CO}_{2}$ into the atmosphere.

\section{INTRODUCTION}

\subsection{Research Background}

Globally, in the world, peatland cover an area of 400 million hectares, equivalent to 3 percent of earth's land area. These ecosystems store most of the existing carbon in the world [1]. This amount is equivalent to the amount of carbon to be emitted into the atmosphere from burning fossil fuels each year. One third of the carbon stored in peatland with in total 191 gigatonnes located in the tropics [2] , in which 60 percents or approximately 25 million acres in Southeast Asia. The majority of peatland in Southeast Asia are found in Indonesia (21 million hectares), while Malaysia about 2.5 million hectares. Thailand has about 45,000 hectares and a relatively small area is found in Vietnam, Brunei and the Philippines.

Most of Indonesia's peatland are located on the island of Sumatra, especially Riau, Kalimantan, Papua, and a small percentage in Sulawesi region. Peatland have some significant values, both extractive and non-extractive. As extractive materials, peat can be ustilized as energy material (e.g.: charcoal briquettes), seedlings media, and dry land reclamation media. While as non-extractive material, peatland can serve as a habitat for animals.
The spread of peatland is predominantly located in the east coast of the Sumatra Island, western and southern coast of the Kalimantan Island, as well as south and north coast of New Guinea. The more accurate dissemination and data of peatland width in Indonesia is uncertain, except Sumatra peat which was relatively widely studied during the opening of Tidal Projects 1969-1984 [3]. Swampland area consists of peatland and mineral soil (non-peat) in Indonesia is estimated 39 million hectares, i.e. approximately one-fifth (19.8 percent) Indonesia's land area. Based on the figure, there are approximately 13.5 to 18.4 million hectares peatland soil or an average of 16.1 million hectare.

Based on natural fertility, peat is divided into three groups, namely eutrophic (high mineral content, neutral or alkaline reaction of peat), oligotrophic (mineral content, particularly calcium [Ca] is low, the reaction sour), and mesotrophic (located in between with the $\mathrm{pH}$ about 5, medium alkaline content). Thickness or depth of peat also determines the level of natural fertility and potential suitability for crops. According to Ref. [3], divide the peat in four classes, namely shallow (50-100 centimeter), somewhat deep (100-200 centimeter, deep (200-300 centimeters), and very deep (more than 300 centimeter).

The sustainability of peatland is currently headed for extinction in an alarming rate. Most of the natural ecosystems in Sumatra and Kalimantan have been converted to agricultural land and oil palm plantations [4]. Peat ecosystem is a unique region 
where the layers comprised of dead organic materials preserved for thousands of years ago and the surface inhabited by various kinds of plant and wildlife. If the organic material beneath it and the life on it destroyed, this ecosystem will be difficult to be recovered.

\subsection{Literature Review}

\subsubsection{Peat as Carbon Reservoir}

Plants need sunlight, $\mathrm{CO}_{2}$, water, and nutrients absorbed from the soil used for growth. The uptake of the photosynthetic material then deposited in the plants body such as leaves, stems, twigs, flowers, and fruit. The $\mathrm{CO}_{2}$ accumulation process is called carbon sequestration. Calculation of the $\mathrm{C}$ content stored in the plant body can be calculated as $\mathrm{CO}_{2}$ in the atmosphere absorbed by plants. $\mathrm{C}$ measurements are still stored in the plants that have died may also illustrate that no $\mathrm{CO}_{2}$ is released into the air through the combustion process.

\subsubsection{The process of carbon accumulation}

Long-lived plants that grow in forests or inter-cropping land are a landfill or storage of $\mathrm{C}$ is much larger than seasonal crops. Therefore, a natural forest with diverse of long-lived trees and many litter is a high $\mathrm{C}$ storage. When the plants on the forest release $\mathrm{CO}_{2}$ into the air through respiration and litter decay, the release occurs gradually, but not as much when there is combustion that releases large amounts of $\mathrm{CO}_{2}$. When forest is converted to agriculture or plantation, the quantity of $\mathrm{C}$ storage will decrease. Along with environmental development efforts, the amount of $\mathrm{CO}_{2}$ in the air should be controlled by increasing the amount of $\mathrm{CO}_{2}$ uptake by plants as much as possible and reducing the release of $\mathrm{CO}_{2}$ into the air to a concentration as low as possible. Thus, maintaining the integrity of natural forests, planting trees on farmland, and protecting peatland are essential to reduce the excessive amount of $\mathrm{CO}_{2}$ in the air.

High containing $\mathrm{C}$ peat is very much flammable in dry conditions. In the event of fire, the flames will continue to propagate into the lower layer and continue to smoke. Release of smoke can be continued until the peat organic matter discharged. Peat fires threaten social, economic, and human ecology. Water is the foundation of peatland. By the nature of the peat that is easy to absorb water, when trees are cut and land opened, there will be a decrease in land (subsidence) so that the hydrophobic nature of peat soils can no longer absorb water and eventually dried up. In the event of the opening of the peat, it will affect the hydrological unit. In this process, there was a release of carbon and cause in peatland vulnerable to fires, which in turn can contribute to the release of carbon emissions further.

$\mathrm{CH} 4$ emissions in peatland will be higher if the depth of ground water level is near or right on the surface of the peat [5]. $\mathrm{N}_{2} \mathrm{O}$ emissions from soil are usually a byproduct of $\mathrm{NH} 4+$ denitrification to NO3- into $\mathrm{N}_{2} \mathrm{O}$ or nitrogen $\left(\mathrm{N}_{2}\right)$. Several factors affect the release of $\mathrm{N}_{2} \mathrm{O}$ are soil moisture, temperature, waterfilled pore space, and the concentration of mineral $\mathrm{N}$ [5].

The amount of $\mathrm{C}$ in aboveground biomass in peat swamp forests ranged between 242-518 tonnes $\mathrm{C}$ per hectare for undisturbed natural forests, 110-221 tonnes $\mathrm{C}$ per hectare of disturbed forest due to selective logging, and between 89-237 tonnes of $\mathrm{C}$ per hectares of burned forest [6]. According to Rieley and Page [7], peat swamp forests of Indonesia have an average of 120-150 tonnes $\mathrm{C}$ per hectare in the biomass above ground and ten-fold greater in the peat below the soil surface (or about 2,500 tons of $\mathrm{C}$ per hectare), or in total of peat swamp forests store an average of approximately 2650 tonnes $\mathrm{C}$ per hectare.

Land in the forest has quite high plants diversity. Actually peatland has very low fertility that making it unsuitable for crop cultivation, without technology treatment or fertilizer inputs. The circumstances which are always flooded make peat tends to anaerobic, acidic with a $\mathrm{pH}$ of 3-5, poor availability of macro (K, $\mathrm{Ca}, \mathrm{Mg}, \mathrm{P})$ and micro $(\mathrm{Cu}, \mathrm{Zn}, \mathrm{Mn}, \mathrm{Bo})$ nutrients, contain toxic organic acids, low cation exchange capacity, and low saturation of alkali. Peat has a very low bulk density because it has large pores. Thus, the peat has very low ability to withstand soil, so the weight is very light and cohesion ability is also low. That is why the trees planted in peatland is very easy to fall and not suitable as building construction material.

Peat also has rapid horizontal hydraulic conductivity so it can accelerate the leaching of nutrients into drainage channels. On the other hand, the capacity of water conduction in the vertical direction is very low. This causes the top layer of peat is often seen dry, even when the bottom layer is wet. It is also an obstacle to agriculture because of water supply to the layers of growth roots in the upper layer becomes blocked and make the top layer of peat is vulnerable to fire.

Peat has high porosity which can absorb large amounts of water from the dry weight of the peat itself so that it can function as a hydrology regulator. Because the peatland bed has the ability to function as a giant reservoir of fresh water, peatland can act as a flooding deterrent during the rainy season and release water slowly into the surrounding region during the dry season. However, the character of peat with a high porosity and high water absorbing properties cannot return when dried. It means the peat ability to absorb water cannot return to its original capacity when the peat has been experiencing extreme drying. As a result, the peat will gradually experience compaction and surface reduction. Other following impact is the peat surface along the coast vulnerable to rising sea levels and flooding, and faster weathering.

\subsubsection{Global Warming and Peatland}

Global climate change is characterized by the tendency of climate change and increase in average temperature near the surface of the earth's atmosphere and ocean that occurred in the last decade. The trend is projected to continue in some time to come, especially if there is no attempt to minimize it.

Climate change is characterized by changes in temperature and rain precipitation patterns. Largest contributor to climate change is increasing concentrations of atmospheric greenhouse gases such as $\mathrm{CO}_{2}, \mathrm{CH}_{4}$, and $\mathrm{N}_{2} \mathrm{O}$. The greenhouse gases absorb the heat radiation wave length and along with increasing greenhouse gases that cause the Earth's surface temperature rises. The increased global temperatures will affect the pattern of weather temperature; change the distribution of rain, and wind direction and speed. This will have a direct impact on other aspects of life in the world, such as changing schedules of rain and drought greatly affects the cropping pattern in Indonesia.

According to Ref. [8], land-use-change changes of peatland into oil palm plantation led to a potential total emissions (global warming potential) between 11 to 21 tonnes of kilograms of $\mathrm{CO}_{2}$ per hectare per year, and environmental degradation can only be restored to normal as they are within 200 to 560 years into the future. 
Most of the peatland and forests in Indonesia are now very badly damaged as a result of human activities which are environmentally harmful. These activities include clearing and burning of peatland in preparing land for agriculture and plantations, uncontrolled peat forest logging for timber, construction water channel for agricultural irrigation and drainage and means of transportation, as well as the opening/conversion of peatland for agriculture, industrial estates, housing, and so forth. These activities do not only cause physical damage to peat land and forests (such as subsidence (sinking of land), the burning and reduced extent of peat), but also cause loss of peat function as carbon storage (reservoir) and absorber (sequester), as the water catchment areas (recharging) that is able to prevent flooding in surrounding areas during the rainy season, and prevent seawater intrusion in the dry season. In addition, destruction of forests and peatland also cause loss of biodiversity and natural resources therein.

The main cause of peatland deforestation in Indonesia is the development of oil palm plantations [9]. Excessive exploitation of peatland with palm trees which currently account for 85 percent of world supply of crude palm oil aims to supply the needs of the market in China, India, and Europe. If the demand for palm oil increases, there will be a very excessive pressure on peatland in the region. For example, in order to replace one percent of the use of fossil fuels with biofuels for power production, Europe will boost oil production at least 2 million hectare of oil palm land $[10,11]$.

Any conversion and drying of the area will result in peat ecosystems degradation that can never be restored. When it happens, peatland will begin to decompose and release carbon into the atmosphere in large quantities. Peat surface will recede much more deeper and very likely lead to the ground surface sink to the bottom of the sea forever [12]. Approximately five percent of the carbon of the earth is estimated to include tropical peatland [7].

Increased concentrations of greenhouse gases in the atmosphere, other than due to increased human activity in burning fossil fuels, the much larger effect is the over-exploitation of peatland producing emissions of $\mathrm{CO}_{2}, \mathrm{CH}_{4}$, and $\mathrm{N}_{2} \mathrm{O}$ and produced very high greenhouse gases. It will directly affect the climate change with massive effects. The carbon stocks will subsequently have major implications for the balance of carbon in the atmosphere. Climate change has led to an increase in temperature of the earth and the end of the weather anomaly that caused a huge impact for the life of mankind and the environment.

\subsection{Research Objective}

This paper speficically reviews the peat as a carbon sink, peat and climate change, potential and constraints of peatland, and the use of peatland as sustainable agriculture land through (1) Peatland Management, (2) Peatland Management Mitigation, and (3) Adaptation Through Sustainable Agricultural Systems.

\section{MATERIALS AND METHODS}

To answer the questions on how to reduce the more severe damage to the peatland areas and minimize the release of $\mathrm{CO}_{2}$ into the atmosphere, two stages of data collection are performed:

\subsection{A. Paper Selection}

20 references are used in this review, mainly the result of a selection of international peer reviewed publications in English derived from major academic article databases.

\subsection{Content Analysis}

Content analysis was carried out on selected references to get the major finding from each references.

\section{RESULT AND DISCUSSION}

\subsection{Peatland Management}

Peatland management indeed is not an appropriate term because of shrinking resources and the presence of subsidence during its use for agriculture. However, it can be reduced in the sense of extending the life span through the minimization of subsidence rate by adopting a proper strategy on water, soil and plants management.

\subsubsection{Water Management}

\section{Drainage}

Drainage is a prerequisite for agriculture, although it is not an easy to do given the nature of peat shrinkage, and unreturned dry due to drainage. Therefore, before the reclamation of peatland, note the specific nature of peat, namely the role and function for the environment. Good drainage for peat agriculture is still maintaining a critical watershed limit, but did not create losses to crops that will influence the harvest. Drainage intensity varies, depending on natural conditions and rainfall. High rainfall (40005000 millimeters per year) [13] requires a drainage system to minimize the effects of flooding.

After drainage and peatland clearing, relatively fast subsidence generally occurs that would result in a decrease of the soil surface. Subsidence and decomposition of organic materials can cause problems if the minerals beneath the peat layer plate consisting of pyrite or quartz sand. Low bulk density resulted in the ability of peat soils to hold (bearing capacity) is also low. Therefore, mechanical cultivation or with livestock is difficult. The low ability to withstand is also a problem for plants and trees or crops that are susceptible to lodging [14]..

\section{Irrigation}

When a critical limit of water can be controlled at optimum levels for plant growth, water management is not a problem, except in the early stages of plant growth. If the critical limit of water cannot be controlled and lower than the sufficient need for water, irrigation needs to be done, especially for certain crops. It is important to supply the water needs of plants and avoid the nature of unreturned dry. Leafy vegetables wither on the state of hot air. This condition may be the influence of the shallow soil profile that can be achieved by plant roots and water loss due to transpiration is faster than the mineral soil [13].

\section{Flooding}

To minimize the occurrence of subsidence, one step that can be done is to keep the waterlogged conditions by adopting a kind of hydrophilic plants or water tolerant plants that provide economic value, such as Eleocharis tuberosa, china spinach 
(Amaranthus hybridus), water spinach (Ipomoea aquatica), and water celery.

\section{Land Management}

Peat soil is actually a good soil for plant growth when viewed from the number of pores associated with the exchange of oxygen for plant root growth. High water holding capacity than the mineral soil causes plants to grow faster. However, the existence of the other inherent properties, i.e. high acidity, low base saturation, and poor macro and micro nutrients, causing the peat soil is classified as marginal [15]. Therefore the effort to manage the land properly is required.

\section{Biomass combustion}

Combustion is the traditional way which is often carried out by the farmers to reduce peat soil acidity level. Combustion of organic material to ash resulted in the destruction and reduction in soil surface. Combustion significantly affect plant growth in the first year and increase plant $\mathrm{P}$ uptake, but lower uptake of $\mathrm{Ca}$ and $\mathrm{Mg}$ [17]. Combustion should be localized so as not to spread to the old peat to be extinguished. The effect of these fires is the high $\mathrm{CO}_{2}$ gas released into the atmosphere. Therefore, there needs to be awareness of the responsible party for this activity.

\section{Nutrient additions}

Provision of fertilizer and amendments in the right composition and dose can overcome the problem of peat soil acidity and nutrients. Nutrients generally need to be added in the form of fertilizers are $\mathrm{N}, \mathrm{P}, \mathrm{K}, \mathrm{Ca}, \mathrm{Mg}$, and a number of micronutrients, especially $\mathrm{Cu}, \mathrm{Zn}$, and Mo. Giving $\mathrm{Cu}$ thought to be more effective through leaves (foliar spray) because of its strong attachment on peat, less mobile in the plant, and the solubility decreases as $\mathrm{pH}$ increases due to flooding. As an amendment, the ash from peat burning will lower soil acidity, supply nutrient, and accelerate the establishment of better physical layer [14].

Manure, chicken manure in particular, contains some elements of specific macro and micro nutrients in greater amounts than other manure. The alkaline saturation is high, but cation exchange capacity is low. Chicken manure, in releasing its nutrients, proceeded in a gradual and long manner. It seems that the provision of chicken manure allows improving the peat soil physical and chemical properties. On sweet corn, providing chicken manure up to 14 tonnes per hectare on the interior peat soil can increase the number of cobs [16].

\subsection{Peatland Management Mitigation}

According to Ref. [18], biomass plants in the wetland forest stores about 200 tons of $\mathrm{C}$ per hectare. Stored carbon is lost quickly when forests are cleared. Logging followed by burning will accelerate the process of emission from peat forest biomass. If the peat forests biomass plant burned, not only the plants biomass that will burn, but also a few inches above the peat layer which is in the dry state. This peat layer will be vulnerable to fires if the water table deeper than 30 centimeter. Combustion of biomass has to be done with extra caution in order not to cause a widespread fire. Therefore, this activity must be supervised correctly, with clear person in charge, and done only as needed. This is because when burning extends to peatland, it will cause the peat fires release carbon into the atmosphere.
Based on United Nations study released by the Food and Agriculture Organization in 2010, modern farming has largely increased the greenhouse gas emissions into the air. This is due to the number of parameter to produce livestock that emit enormous gas emissions. Maintenance of livestock requires electrical energy for the lights and ancillary equipments, ranging from heating, mowers, etc. One of the largest electrical inefficiency comes from cooling machines for meat storage, both on farms and the stations (distributors, retailers, restaurants, and market) before the meat arrives at the house/dining plate. Refrigeration machines are electronic devices that are very wasteful of electricity/energy. Not to mention the problem of transportation used, both for transporting livestock, fodder, and other elements to support the farm.

Therefore, the chicken manure used for the addition of nutrients should chicken manure kept by the rural community in the peatland areas, instead of bringing from non peat locations, which will certainly contribute more emissions. The use of chicken manure is recommended not to be excessively in quantity, but used sparingly to add much needed nutrients to the peat with deficiency of certain nutrients. The use of chicken waste could serve as additional income and nutrition improvement of families living in remote peatland areas.

\subsection{Adaptation Through Sustainable Agricultural Systems}

The potential for agricultural development on peatland is largely determined by the level of farm management which will be applied, in addition to the peat natural fertility. The peatland management at farmers level, with farm management including categorized as low to medium inputs, will vary with the productivity of the high level management done by private or large company.

Until now the use of peatland for agriculture are still pro and contra between the various parties, although the utilization which has been done not yet providing tangible maximum results. In agriculture development, peatland is a land that has always been the main topics to be discussed in more depth. The large-scale project in the 1990s, opening a million hectares of peatland in Central Kalimantan to achieve rice self-sufficiency goal, caused the peatland area acreages dropped massively. In addition, the higher the demand for oil palm exports will lead to the flourishing of plantations that have spurred the opening of peatland on a large scale. Of course the changes of peatland into rice fields and oil palm causes the degradation of environmental quality that has an enormous impact to the lives of farmers, and social economic development in the region. Frequent smoke that covered the sky and makes the chest tightness is a common thing in the area around the peat and cause smoke "exported" to the neighboring countries such as Singapore and Malaysia. It should now be removed; at least the "export" of the smoke from forest fires is reduced through decisive action and the willingness of farmers in these peatland areas.

Noticing physical and chemical properties of peat, peat ecosystem vulnerability, the barriers facing agricultural development in peatland, and welfare of farmers, strategy need to be formulated to ensure sustainable use of peat in the development of agricultural crops. To maintain the sustainability of agricultural activities in the peatland, Ref. [14] suggest three things to do. First, maintaining the economic value of agricultural systems in accordance with the local conditions of the peat. 
Second, maintaining the peat agricultural resources. Third, maintaining other ecosystem influenced by agricultural activities in the peatland.

\subsubsection{Selection of Plant Type}

Paddy cultivation always strived by transmigrant farmers to meet their food needs. However, rice cultivation in peatland faced various problems, especially in regard to the physical constraints, fertility, soil and water management. In particular, thick peat (more than one meter) has not been successfully utilized for the cultivation of rice because it contains a number of limitations that cannot be solved. The key to the success of rice cultivation on peatland lies in the water management and control, the handling of a number of physical constraints which is a limiting factor, the handling of toxic substances, as well as macro and micro element fertilization [14].

Peatland suitable for rice field is very shallow (20-50 centimeter) and shallow peat (0.5 to 1 meter). Rice is not appropriate in middle peat (1-2 meter), thick peat (2-3 meter) and very thick one (more than 3 meters). In the thick and very thick peat, the rice plant cannot yield food grain due to scarcity of micro nutrients [3]. In the paddy soil with high organic matter content, organic acids inhibit growth, especially the roots, resulting in low productivity, and even crop failure. Ref. [14] demonstrated the close relationship between the thickness of peat and paddy rice production. In the pot experiment with soil taken from the 0-20 centimeter layer, the rice grain yield obtained (planted in the rice field is very low when the thickness of peat more than 80 centimeters and maximum harvest when the peat thickness is 50 centimeter.

\subsubsection{Plantation and Industrial Crops}

Cultivation of large-scale plantation crops largely developed on peatland, mainly by private companies. Cultivation of these crops mostly developed in Riau Province by using thick peat. Before planting, soil compaction was done by using heavy equipment. Proper drainage system will determine the successful cultivation of crops on the land. The major management of soil fertility is macro-and micro-fertilization [15. Plantation crops are suitable to grow on thick (1-2 meter) and very thick peat (2-3 meter) [3] .

In Malaysia, among the plantation crops like oil palm, sago, rubber, coffee, coconut, pineapple (Ananas cumosus) are plants that show high adaptability on drained peat. Pineapple can adapt well to the state of high acidity and low fertility rates. Oil palm is one of the perennial plants that are quite appropriate to moderate thickness to thin peat soil with the results of about 13 tonnes per hectare in the third year of planting [13]. Other commodities of economic potential to be developed to meet the domestic needs are industrial plant such as coconut, coffee, pepper, and herbs [19].

\subsubsection{Food Crops and Other Seasonal Plants}

Peat soils suitable for annual crops are shallow and medium peat. Water management should be observed that ground water does not go down too deep or drastic to prevent the occurrence of unreturned dry symptoms [3]. Food crops require good drainage to prevent rot disease at the bottom of the plant and minimize the use of fertilizers. Cassava (Manihot esculenta) or tapioca produces more than 50 tons per hectare with good management and is an important food crop in tropical oligotrophic peat with good drainage.

In the vegetable producing areas in Central Kalimantan, farmers developed a vegetables like collards, kale, cucumbers, cultivated in monoculture on a small scale land approximately 0.25 hectares [15]. In addition, some peatland categorized as bongkor (abandoned) land can be cultivated for various crops, such as the great/curly/small chili, eggplant, tomatoes, cabbage, celery, scallion, bean, pariah, cucumbers, corn, vegetables, sweet corn, and fruits (mango, rambutan, melinjo, breadfruit, jackfruit, papaya, pineapple, banana), because the peat is C/D type (not influenced by tidal water, ground water seepage only through more than 50 centimeters below the soil surface during the dry season and less than 50 centimeter in the rainy season) [20].

\subsubsection{Cultivation Techniques}

To avoid a decline of peat soil surface through biochemical oxidation, the surface must be maintained for not being bald. Some vegetation, such as grasses or legumes, may be allowed to grow around the plant, except in the main planting hole with like in oil palm and coffee plantation. It would be better if the remains of weeding returned to the ground or buried, which will serve as the compost so that in addition to providing additional nutrients may also help maintain a reduction in soil surface through subsidence [13].

For horticultural crops, the burning of litter can be done in a special place with the size of $3 \times 4$ meters. The kiln is given mineral soil/clay with 20 inches thick and a channel as wide as 30 centimeters built around the kiln. The depth of channel adjusted to depth of groundwater and the water levels maintained 20 inches from ground level to make the peat remain fairly wet. This meant that at the time of burning, the fire did not spread-out [20].

\subsubsection{Soil compaction}

Soil compaction is required for plantation crops like oil palm, coconut, and rubber. The low bearing capacity of peat soils can lead to easy tree felling and decrease production. Soil compaction needs to be done in oil palm plantations in order to increase density, the pores and roots grip the soil stronger so that plants felling can be reduced [15], [14]. Soil compaction will also improve the harvest because the magnitude of plant nutrient uptake after more peat granules interacts with plant roots.

\subsubsection{Conservation of Peatland Agricultural Resources}

Peatland conservation aims to preserve the peat existence from extinction and maintain the peat ability to store water. Both of these activities linked very closely with each other. To sustain peat resources for agriculture, peat water management control is very crucial and the ground water level should be tailored to the rhizosphere needs of the plant. The awareness that peat is a planting medium that must be preserved should be should raised among the public, excessive burning during land preparation should be avoided as far as possible, fuel ash making technologies by burning garden waste and weeds can be done in a controlled manner in a burning hut as done by vegetable farmers. Direct burning of bushes and weeds in the garden will cause the burning of peat. Uncontrolled combustion will lead to rapid loss of peat, 
in addition to causing smoke pollution that harms many people in a long time.

Noticing the essence of the explanation above, there are steps that can be done as sustainable agricultural applications by always paying attention of the peatland condition and the environmental quality that have been degraded. Excessive use of inorganic fertilizers should not be implemented in peatland area because it can produce high emission. This has been confirmed by Ref. [18] that the use of inorganic fertilizers may increase crop production, but simultaneously increase the rate of gas emission into the atmosphere. In addition, the opening of peatland for agricultural areas must have a good reason and control system. Many communities in the rural areas are classified as "nomadic" in making a living of horticulture agriculture by illegal logging and burning in order to obtain land for cultivation. An effort should be taken to minimize such agricultural practices to keep peatland remain intact can reduce the negative impacts on the surrounding environment.

\section{CONCLUSION}

Peatland is a land with very large carbon content. The higher demand for oil palm products and the conversion into seasonal crop growing areas will lead to higher peatland clearing in Sumatra and Kalimantan. Without any attempt to reduce them, peatland will eventually bring negative impact on the surrounding natural environment and enhance the greenhouse effect that may lead to changes in climate on earth. Peatland ability to absorb carbon should be protected by not over-exploited for the development of agriculture and plantation industries, and utilized according to local wisdom used and must be clearly intended to improve people's lives around the peatland. Hence, it needs a wise and prudent management in order to remain sustainable. Expansion of agriculture should be in accordance with the nature and conditions of peatland in order to obtain an optimal agricultural output and prevent the larger emission of peatland because these emissions really contribute to climate change and global warming as it is today.

\section{ACKNOWLEDGMENT}

The authors would like to thank the the Ministry of National Education for their financial support. We also thank Peatland Research Institute, for supplying the information needed to conduct the presented study..

\section{REFERENCE}

[1] Strack, Maria (2008), Peatlands and Climate Change, University of Calgary, Canada

[2] Page, S.E. and Rieley, J.O. (1998) "Tropical Peatland: A Review of Their Natural Resource Functions, with Particular Reference to Southeast Asia", Quaternary Research 8: 95-106.

[3] Subagyo, Marsoedi, and Karama, S. (1996) "Prospek Pengembangan Lahan Gambut untuk Pertanian"

[4] Harsono, S.S, Grundmann, Philipp; Lau, Lek; Hansen Anja; Salleh, M.A; Meyer-Aurich A., Idris A; , Mokh Ghazi T. (2013), Energy balances, greenhouse gas emissions and economics of biochar production from palm oil empty fruit bunches, Resources, Conservation

[5] Melling, L., Hatano, R., and Goh, K.J. (2005) "Methane Fluxes from Three Ecosystems in Tropical Peatland of
Sarawak, Malaysia", Soil Biology and Biochemistry 37: 1445-1453.

[6] Ludang, Y. and Jaya, H.P. (2007) "Biomass and Carbon Content in Tropical Forest of Central Kalimantan", Journal of Applied Sciences in Environmental Sanitation 2: 7-12.

[7] Rieley, J.O. and Page, S.E. (2008) Future of Tropical Peatland in South East as Carbon Pool and Sink, Paper presented at the International Peat Congress in Tullamore, Ireland.

[8] Harsono, S.S., Prochnow, A., Grundmann, P., Hansen, A., and Hallman, C. (2011) "Energy Balances and Greenhouse Gas Emissions of Palm Oil Biodiesel in Indonesia”, Global Change Biology and Bioenergy 4 (2): 213-228.

[9] Murdiyarso, D. and Kanninen, M. (2008) "Forests and Climate Change: An Outlook of Asianforests in the New Climate Regime" in Loh, C., Stevenson, A., and Tay, S. (ed.) Climate Change Negotiations: Can Asia Change the Game?, Hong Kong: Civic Exchange, 74-87

[10] Reinhardt, G., Rettenmaier, N., dan Gärtner S. (2007) Rain Forest for Biodiesel? Ecological Effects of Using Palm Oil as a Source of Energy, Frankfurt: World Wildlife Fund Germany.

[11] Harsono, S.S., Prochnow, A., Grundmann, Soebronto S. (2014). Anaerobic treatment of palm oil mill effluents: potential contribution to net energy yield and reduction of greenhouse gas emissions from biodiesel production. Journal of Cleaner Production, 64 (2014) 619 $-627$

[12] Hooijer, A., Silvius, M., Wösten, H., and Page, S. (2006) PEAT-CO: Assessment of $\mathrm{CO}$ emissions from drained peatland in SE Asia, Delft Hydraulics Report Q3943.

[13] Ambak, K. and Melling, L. (2000) "Management Practices for Sustainable Cultivation of Crop Plants on Tropical Peatland", Prosiding Simposium Internasional Lahan Gambut Tropis (Proceedings of International Symposium on Tropical Peatland) on November 22-23, 1999 in Bogor.

[14] Rajaguguk, B. (2004) "Developing Sustainable Agriculture on Tropical Peatland: Chalanges and Prospects" in Palvanen, J. (ed.) "Wise Use of Peatland", (Proceedings of the International Peat Congress) in Tampere, Finland in June 6-11, 2004, 707-712.

[15] Limin, S., Layuniati, and Jamal, Y. (2000) "Utilization of Inland Peat for Food Crop Commodity Development Requires High Input and is Detrimental to Peat Swamp Forest Ecosystem", (Proceedings of International Symposium on Tropical Peatland) on November 22-23, 1999 in Bogor.

[16] Darung, U., Mimbar, S.M., and Syekhfani (2001) "Pengaruh Waktu Pemberian Kapur dan Pupuk Kandang terhadap Pertumbuhan dan Hasil Panen Kedelai pada Tanah Gambut Pedalaman Kalimantan Tengah" ("The Effect of Lime and Manure Provision Time on Soybean Growth and Harvest in Inland Peat Soil of Central

[17] Mawardi, E., Azwar, and Tambidjo, A. (2001) "Potensi dan Peluang Pemanfaatan Harzeburgite sebagai Amelioran Lahan Gambut" ("Potential and Opportunity of Harzeburgite Utilization as Amelioran Peatland"), Prosiding Seminar Nasional Memantapkan Rekayasa Paket Teknologi Pertanian dan Ketahanan Pangan dalam Era Otonomi Daerah (Proceedings of the National Seminar on Strengthening the Agriculture and Food Security Technology Engineering in Regional Autonomy Era) on October 31-November 1, 2001 in Bengkulu.

[18] Rahayu, S., Lusiana, B., and van Noordwijk, M. (2005) "Above Ground Carbon Stock Assessment for Various Land Use Systems in Nunukan, East Kalimantan" in Lusiana, B., van Noordwijk, M., and Rahayu, S. (ed.) 
Carbon Stock Monitoring in Nunukan, East Kalimantan: A Spatial and Modelling Approach, Bogor: World Agroforestry Centre, 21-34.

[19] Abdurachman, A. and Suriadikarta, D.A. (2000) "Pemanfaatan Lahan Rawa eks PLG Kalimantan Tengah untuk Pengembangan Pertanian Berwawasan Lingkungan" ("Ex-PLG Swamp Land Use in Central Kalimantan for Environmental Friendly Agricultural Development"), Jurnal Penelitian dan Pengembangan Pertanian 19 (3): 77-81.

[20] Ardjakusuma, S., Nuraini, and Somantri, E. (2001) "Teknik Penyiapan Lahan Gambut Bongkor untuk Tanaman Hortikultura" ("Peat Preparation Techniques for Bongkor Horticulture Crops "), Buletin Teknik Pertanian 6 (1): 3-6. 